A Journal for Manly Culture: An Exploration of the World's First Gay Periodical

\title{
Andrew Stewart
}

\begin{abstract}
Published by Adolf Brand from I896 until the rise of Nazism in 1933, Der Eigene was the world's first homosexual periodical. This article will argue that although many of the ideals espoused in this publication are now considered at best distasteful and at worst inherently wrong and associated with Nazism, there are elements of the publication that are worthy of greater attention in the historiography. I will begin by exploring the publication itself, its ideals and goals, and how it sought to use art to accomplish them. I will then suggest ways in which Der Eigene challenges our contemporary understanding of homosexuality by tracing clear links from ideas put forth by its contributors to elements of the modern LGBTQ community.
\end{abstract}

\section{Résumé}

Publié par Adolf Brand à partir de 1896 jusqu'à la montée du nazisme en 1933, Der Eigene était le premier périodique homosexuel au monde. Cet article soutiendra que même si plusieurs idéaux mis de l'avant par cette publication sont désormais considérés, au mieux, répugnants et, au pire, fondamentalement inacceptables et liés au nazisme, d'autres éléments méritent une plus grande attention dans l'historiographie. Je commencerai par une exploration de la publication elle-même ainsi que ses idéaux, ses objectifs et les moyens par lesquels elle cherche à employer les arts afin de les atteindre. Ensuite, j'examinerai comment Der Eigene complique notre compréhension contemporaine de l'homosexualité en traçant des liens entre les idées avancées par ses contributeurs et certains éléments de la communauté LGBT moderne. 
Als Ehrenmitglied Ihrer Gesellschaft fühle ich mich verpflichtet, Ihnen über die völlige Aussichtslosigkeit einer Fortsetzung meiner Lebensarbeit im neuen nationalsozialistischen Deutschland einen ausführlichen Bericht zu geben ... Unmittelbar nach der Machtergreifung begann die Regierung des deutschen Bundeskanzlers Adolf Hitler sofort, alle erdenklichen strengen Maßnahmen zur Unterdrückung der Homosexuellenbewegung zu ergreifen.

As an honorary member of your society, I feel obliged to give you a detailed report on the complete futility of continuing my life work in the new National Socialist Germany ... Immediately after the seizure of power, the government of the German Chancellor Adolf Hitler began to take all conceivable strict measures to suppress the homosexual movement.

Adolf Brand, letter to the Gemeinschaft der Eigenen, 29 November $1933^{1}$

In 1933, shortly after Hitler's rise to power, the Nazis raided a private home in a quiet suburb of Berlin on five different occasions. The home belonged to Adolf Brand, a German writer, publisher, egoist anarchist, and homosexual. During the first and subsequent raids, officers removed materials related to the publication of Der Eigene (His Own Man, or Unique One), a journal Brand produced on behalf of the Gemeinschaft der Eigenen (Society of Self-Owners). Der Eigene, which had been in print since 1896 , began as an anarchist publication, but refocused in 1903 on promoting the acceptance of male bisexuality and homosexuality. The irregularly published journal compiled cultural, artistic, and political content, including prose, political manifestos, nude photography, and lyric poetry. The confiscated materials were handed over to Ernst Röhm, an early member of the Nazi party and close friend of Adolf Hitler. This would spell the end of Der Eigene, the world's first homosexual publication.

The history of Adolf Brand and Der Eigene has been largely overlooked by historians, despite its large readership and lengthy publication run. One reason for this is the relative scarcity of remaining copies and the dearth of associated records. As Harry Oosterhuis explains in his edited volume Homosexuality and Male Bonding in Pre-Nazi Germany, study of Der Eigene is hindered by the fact that much of the material related to the publication was

I This letter has been republished, in German, on the GLBT-News Israel website: http://glbt-news.israel-live.de/ns-zeit/adolf-brand.htm. 
destroyed by the Nazis. In addition, many of the men involved with the publication were murdered by the Nazis; even Röhm, an open homosexual, was later executed during the Night of the Long Knives. Oosterhuis attempts to remedy this scarcity, at least in part, by reproducing key articles from Der Eigene, organized around major themes. He provides valuable introductions to each of these themes, offering some historical context and explaining key issues, but also notes that he wants the articles to "speak for themselves" and allow readers to "work out for themselves what is objectionable and what is still worthy of consideration."

Oosterhuis's insistence that readers must make up their own mind about Der Eigene's legacy is a gesture toward another reason why the journal has not received much attention over the years. Although Der Eigene began as a predominantly anarchist political journal, Brand's interests lay in masculinist theories about sex, sexuality, and eugenics. According to Marita Keilson-Lauritz, contributors to Der Eigene not only desired a revival of Greek pederasty as a cultural model, but they also believed in the inherent bisexuality of all men. ${ }^{3}$ Brand idealized the so-called Übermensch, a kind of super-man or hyper-man conceptualized by philosopher Friedrich Nietzsche and later adopted by Hitler to describe a biologically superior Aryan or Germanic master race. Thus, more than scarcity, it is the tone and content of Der Eigene that has discouraged researchers from investigating the journal and its impact. Today, Der Eigene is mainly used as a counterpoint in discussions about Magnus Hirschfeld and the Scientific-Humanitarian Committee, which advocated for the repeal of Paragraph 175 of the Imperial Penal Code, which criminalized "coitus-like" acts between males. While Hirschfeld is remembered as a pioneering activist for homosexual and trans rights, Brand's legacy is aligned more with fascism than modern ideas about gay liberation. In fact, Hirschfeld's ideas about sexuality are so dominant in the construction of homosexuality that Robert Beachy, who has written

2 Harry Oosterhuis, "Homosexual Emancipation in Germany before 1933: Two Traditions," in Homosexuality and Male Bonding in Pre-Nazi Germany: The Youth Movement, the Gay Movement, and Male Bonding before Hitler's Rise, ed. Harry Oosterhuis and Hubert Kennedy (New York: Harrington Park Press, I99I), I-27 (20-2I).

3 Marita Keilson-Lauritz, Die Geschichte der eigenen Geschichte: Literatur und Literaturkritik in den Anfängen der Schwulenbewegung am Beispiel des Jahrbuchs für sexuelle Zwischenstufen und der Zeitschrift Der Eigene (Berlin: Verlag Rosa Winkel, 1997). 
about homosexuality as a German invention, relegates Der Eigene to a footnote, simply stating that it was a "homosexual literary journal" and that Brand also published a "range of books and pamphlets."

In this essay, I argue that Der Eigene deserves more attention, not just because the publication has literary and artistic merit worthy of study, but also because its content reflects a particular homosexual identity that persists in contemporary queer communities. The context of Der Eigene's publication suggests that the German invention of homosexuality was not as coherent as gay liberation theory sometimes purports. Brand believed Der Eigene to be serious art and understood this to be emblematic of the ways in which homosexual men might uplift German society through art and literature. I will describe how the publication used art, including nude photography, in its design and to further Brand's masculinist theories. I will then suggest ways in which Der Eigene challenges our contemporary understanding of homosexuality. Although distasteful by today's standards, the journal's relationship to anti-Semitism, eugenics, and Nazism offers important insight into persistent ideas about masculinity in the gay community and how the Far Right might use homosexuality to further its political and social goals.

\section{Rediscovering a Serious Art}

Although some records related to the publication of Der Eigene were saved by Brand's assistant, Karl Meier, most materials were confiscated during a series of raids in 1933 and later destroyed. ${ }^{5}$ Other materials that could have helped to shed light on the journal met a similar fate. Hirschfeld's Institut für Sexualwissenschaft (Institute for Sexual Science) was also infamously attacked by the Nazis in 1933, and its contents largely destroyed in one of the most iconic examples of book burning in the Third Reich. ${ }^{6}$ Considering the extent to which the Gemeinschaft der Eigenen offered an alternative social space for homosexuals, and for Brand's frequent and public criticisms of Hirschfeld's ideas, it is likely that additional resources helpful to the study of Der Eigene would have been collected there

4 Robert Beachy, "The German Invention of Homosexuality," Journal of Modern History 82, no. 4 (December 2010): 80I-38 (82I), doi: I0.I086/656077.

Oosterhuis, "Homosexual Emancipation in Germany," 7.

6 Heike Bauer, The Hirschfeld Archives: Violence, Death, and Modern Queer Culture (Philadelphia: Temple University Press, 20I7), 78. 
and subsequently lost to the flames. What remains of Der Eigene is largely the volumes of the journal itself, sent to its I, 500 subscribers or purchased in select bookshops and afterward preserved by private collectors or libraries. These volumes, however, are also quite rare. According to OCLC WorldCat, only sixteen institutions in the world hold copies of Der Eigene. ${ }^{7}$ Although this list is not exhaustive and does not account for private collections, it indicates the scarcity of the remaining copies. A search of their catalogues indicates that most of these institutions lack complete runs of the journal as well. The British Library, for example, has only nine issues, from I92I to 1922. The Beinecke Library at Yale University, which holds considerably more volumes from the 1920 and 1930s, has only one volume from before I92I.

What we can glean from the available copies is that the journal's primary goal was to use arts and literature to draw attention to the role of homosexuals as "elite critics of modern society," and that contributors used a combination of poetry, stories, literary critiques, essays, and artwork to demonstrate the superiority of homosexuals in German society. ${ }^{8}$ Essays dealt with a variety of contemporary topics concerning homosexuality, the impact of the women's movement on male culture, the significance of male friendships, and, above all, the meaning and importance of same-sex love. Although essays make up a significant portion of some issues, the Gemeinschaft considered Der Eigene to be primarily an artistic and literary endeavour. Contributors often used artistic critiques to promote what they believed to be a manly culture of friend-love that simultaneously documented examples of same-sex relationships in art and drew attention to the elite status of homosexuals. A salient example of this form of critique is a piece written by Brand in a 1906 issue. Titled "Exlibris von Felix Willmann," the article discusses bookplates created by Willmann that depict strong nude males: one shows a man brandishing a torch at a serpent emerging from a book, another depicts four men holding up stacks of books, and a third shows two men sharing a kiss in a ruined castle as weapons point at them from the bottom of the bookplate. ${ }^{9}$ Brand suggests that these bookplates show the whims and desires of the rich clients who commissioned

See: OCLC WorldCat 47236279I and 559833843.

See: Harry Oosterhuis, "The Aesthetics of the Male Body: Introduction," Journal of Homosexuality 22, nos. I-2 (I99I): 85-92 (86).

9 Adolf Brand, "Exlibris von Felix Willmann," Der Eigene 6 (1906): I86-90. 
them. He also notes that not everyone has a relationship with such an artist, or the means with which to commission such a bookplate, but he hopes that this article will induce some of his compatriots take up this custom of furnishing their books in this manner. Here, Brand critiques the art of these bookplates, using this as an opportunity to highlight the names of prominent men who share similar beliefs, as well as the elite status that readers of Der Eigene occupy as literate men of means. The images themselves also underline the ideological inclinations of the Gemeinschaft, with its focus on manly culture.

In addition to content, the design of Der Eigene was also intended to convey a certain homosexual aesthetic. The format and layout of the journal was irregular, despite some attempts at standardization. Some early issues had cover illustrations and included elaborate designs, such as one 1899 issue which featured a large cover illustration of a young boy sitting at the base of a tree and staring at a Grecian building. To the right of the boy is an intricate border that includes a table of contents, while the title above the scene is printed in type that resembles twigs. ${ }^{10}$ Other issues had considerably plainer covers, like a 1903 issue whereupon the title and issue number were printed in black in the centre, with the imprint and editor information printed at the bottom left of the page. The only decoration on this cover is a small three-leafed clover. ${ }^{\text {II }}$ The majority of issues from the I920s, however, when the journal achieved its peak distribution, have covers of beige paper with regular black borders enclosing images of young men printed separately on white paper and pasted down onto the upper part of the cover. ${ }^{\text {I2 }}$ Other issues from the same decade have the same beige paper covers featuring images of young men, and include bold red lines running parallel to the title and setting it off from the issue and imprint information at the bottom of the page. ${ }^{\text {I3 }}$

The print and paper quality of the journal also suggests that, while Brand attempted to standardize the format and layout, there was considerable variation in overall production quality. Some volumes are printed on low-quality wove paper ${ }^{\mathrm{I} 4}$ while other editions, particularly those from the I920s, are printed on higher-quality wove paper or

See: Der Eigene I, no. I (I899).

See: Der Eigene 2, no. I (1903).

I2 See, for example: Adolf Brand, ed., Die Tänte, special issue, Der Eigene Io, no. 9 (1925); and Der Eigene IO, no. 4 (1924).

13 See: Der Eigene Io, no. 5 (1924).

I4 Der Eigene 9, no. 4 (1924). 
even more costly laid paper. ${ }^{15}$ Issues were also printed in varying formats. The 1925 Die Tänte special issue, which I will discuss later in this article, was produced in octavo, with each gathering stapled together and glued to the covers, ${ }^{16}$ while another 1924 issue is a single gathering of nine sheets folded once and stapled together with a glued-on cover. ${ }^{17}$ Images within the text are either illustrations printed directly onto the page, or photographic reproductions printed on white paper and pasted onto the page. Both techniques can be seen in the Die Tänte issue, which includes satirical illustrations printed with the text, as well as a photograph of a nude man with a dog. The photograph, pasted onto a plate, is off-centre, and demonstrates the difficulties in producing a standardized magazine with the technology available at the time. ${ }^{\mathrm{I}}$

Only one volume of Der Eigene includes a hard cover-the 1906 special edition. This volume is arguably the pinnacle of Brand's desire to produce a journal with artistic and literary merit and was certainly the most far-reaching, with over three thousand copies printed. The volume includes images and design highlighting the elitism of its homosexual contributors and demonstrates the journal's overall engagement with current elements of Germany's culture and historical traditions. The volume is also the largest and most focused issue of the journal's entire run and appears to be a direct response to a lawsuit in which Brand was accused of distributing obscene material. At the trial, Brand's associates, Max Dessoir and Georg Groddeck, testified that Der Eigene was a piece of serious art. ${ }^{19}$ Brand lost his lawsuit and was sentenced to a two-month prison term. The 1906 volume was published shortly after his release and appears to reassert Der Eigene's position as serious art. This volume is bound in octavo format, with each gathering of high-quality laid paper stapled together and then sewn into the binding. Each gathering is separated by a plate mounted on grey wove paper. As in the regular issues of Der Eigene, the plates are pasted onto their sheets, but in this special issue they also contain colour illustrations, each with a description, and are accompanied by protective tissue-paper sheets.

In addition to its superior layout, the 1906 special edition includes a particularly important cover design that represents the Gemeinschaft

Der Eigene Io, no. 3 (1924).

See: Brand, ed., Die Tänte.

Der Eigene Io, no. 3 (1924).

Der Eigene Io, no. 3 (1924).

Keilson-Lauritz, Die Geschichte, 99. 
der Eigenen's idealization of same-sex love and pederasty in ancient Greece. The cover features two Ionic columns, which support a piece of stone in which the title Der Eigene appears in gold. There is also a brazier with gold smoke reaching up to the title, and what appear to be golden flowers dispersed behind the brazier, as though in a garden. The Grecian motifs carry through onto the title page, with an illustration in grey, designed as though carved in stone, of a naked man holding torches, no doubt a reference to the Olympic Games. ${ }^{20}$ By evoking ancient Greece, and the newly revived modern Olympic Games, Brand and his contributors make a claim that same-sex love should be accepted and celebrated in modern Germany as it had been in Greece. As early as 1899, for example, Elisarion von Kupffer argued for the return of Leiblingminne ("chivalric love"), claiming that the demise of this same-sex love had led to the demise of ancient Greece. "Yes," Kupffer writes, "a source of strength: these relationships can be such. If we leaf through the pages of history with open eyes, we will find proof of this. In the first place stands ancient Greece." ${ }^{21}$ Germans, he argues, "stand closest to the Greeks" and should rejuvenate the state and culture as "heirs of Greece."22 Brand used Der Eigene to further this argument and, in particular, the 1906 special edition carries this message forward through its artwork as well as its contents. Inside the volume, Brands includes stories and poems with related themes, images of ancient statues of males, and even a header that features stylized braziers. Many of the interior illustrations are signed by Felix Willmann and a note indicates that the originals are offered for sale separately, underlining the publication's artistic merit. ${ }^{23}$

20 Der Eigene 10, no. 3 (1924): iii.

${ }^{21}$ Elisarion von Kupffer, "The Ethical-Political Significance of Lieblingminne (I899)," Journal of Homosexuality 22, nos. I-2 (I992): 35-48 (40).

22 Harry Oosterhuis, "Eros and Male Bonding in Society: Introduction," in Oosterhuis and Kennedy, Homosexuality and Male Bonding in Pre-Nazi Germany, II9-25 (I20).

23 Adolf Brand and Konrad Linke, eds., Der Eigene: Ein Buch für Kunst und Männliche Kultur, special issue, Der Eigene 6 (1906): 194. 


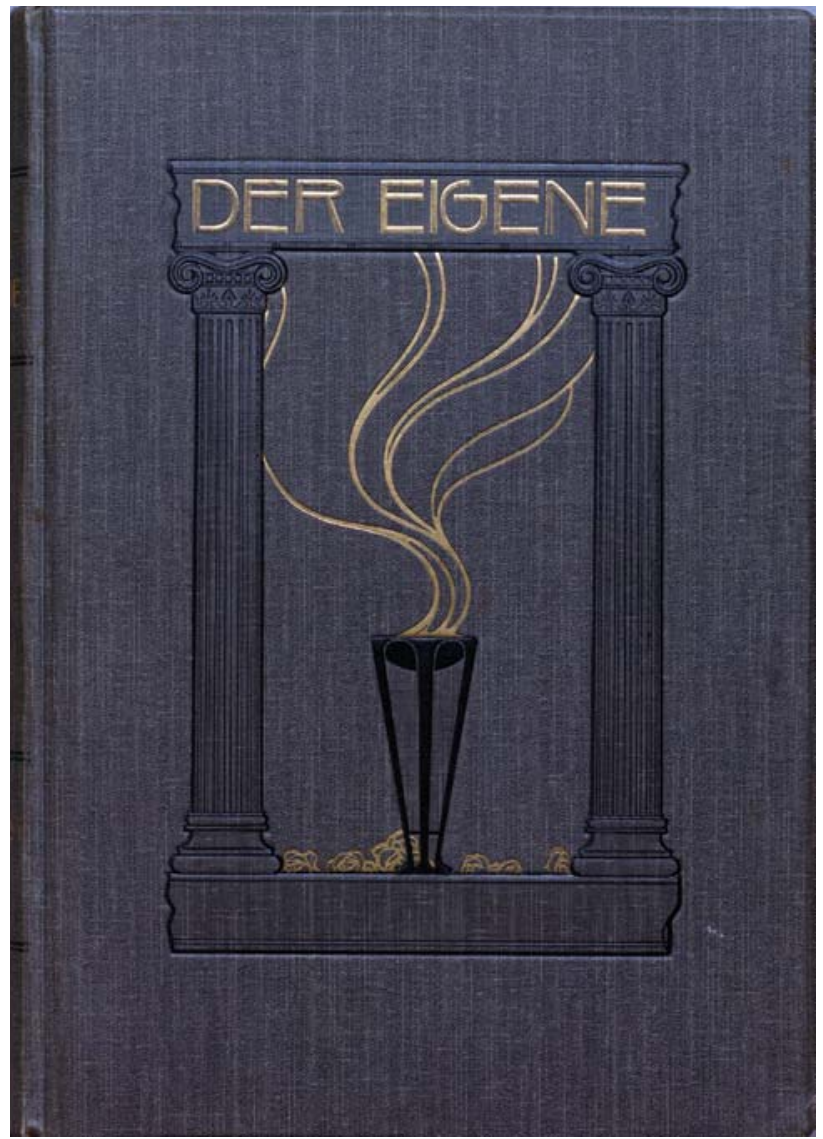

\section{A Better Type of Human Being}

Brand's use of illustration and design to uplift the aesthetics of Der Eigene was complemented by his use of photographs throughout the publication. In particular, Brand prominently featured photographs of nude men; images of naked men, single or in pairs, laying in the grass or posing in natural settings such as forests or beside bodies of water, are most common. One 1924 issue, for example, opens with an image showing two naked young men standing by a tree beside a lake, looking off into the distance. Another image, which appears in the satirical 1925 Die Tänte issue, shows 
a nude man lying down in the grass with a garland of daisies wrapped around his waist, pointing at a small dog which stands on its hind legs facing him. Both images are captioned: "From the collection Deutsche Rasse: A nude study by Adolf Brand." 24 The depiction of attractive and physically fit young men, seemingly comfortable with their bodies, and with each other, evokes the love between friends that was so central to the Gemeinschaft's ideology. Many of the society's members, including Brand himself, were adherents of the Freikörperkultur (nudism) movement. ${ }^{25}$ One of the founders, Heinrich Pudor, was even a contributor to the journal. As Oosterhuis notes, Freikörperkultur reflects the idea that nudism was the "genesis of a new, better type of human being, who was one with nature and had reached physical as well as spiritual beauty." ${ }^{26}$ The image of the man in the grass is clearly an embodiment of these ideals; the photograph celebrates his physicality, while the flowers, dog, and natural setting appear to point to something akin to the spiritual beauty and oneness with nature that were central to the movement.

The captions for these images nevertheless suggest that, although Freikörperkultur was certainly part of the motivation for their inclusion in Der Eigene, there was another, more complicated reason. Deutsche Rasse, meaning "German breed," is a term associated with right-wing ideas about race and nationalism, and the importance of the racial health and purity of the German people. Although Brand's nude photographs often resulted in trouble with the authorities, he was mostly able to defend himself. As Oosterhuis explains, Brand could argue that "his motivation was not sexual but artistic and scientific, and that showing male nudity was in the interest of "racial health and purity." ${ }^{27}$ Brand articulates this clearly in "What We Want," an article that outlines the goals of the Gemeinschaft. The main benefit of nudism, he writes, is that a man would be able to see his prospective wife naked, just as he had seen his friends growing up, and this would, in turn, contribute to the careful sexual selection that assured "racial improvement, sexual health, and advancement

\footnotetext{
24 Adolf Brand, "Aus der Sammlung Deutsche Rasse: Akstudie von Adolf Brand," Der Eigene I0, no. 3 (1924): 91; Adolf Brand, "Aus der Sammlung Deutsche Rasse: Akstudie von Adolf Brand," Der Eigene Io, no. 9 (I925): 439.

25 Oosterhuis, "Aesthetics," 89.

26 Oosterhuis, "Aesthetics," 89.

27 Oosterhuis, "Homosexual Emancipation," 4.
} 
in general. ${ }^{28}$ Brand's belief in racial purity is made even plainer in a subsequent 1930 article, where he writes that parents need to be "noble and flawless in spirit and body. For just as in the production of a noble race of horses or dogs only quite flawless, selected, first-class examples are considered, so too should it also be in an even much stricter way with humans. Whoever brings mentally ill, weak-minded, infirm, or crippled individuals into the world sins against his progeny, his family, and his nation!" 29

Like the journal's Grecian design elements, which tether the kind of friend-love promoted by the Gemeinschaft to an idealized past, depictions of nudity and the male form also serve a rhetorical purpose. They underscore not only friend-love and a celebration of physical and spiritual beauty, but also a shared belief in the benefits of eugenics for the advancement of the German race.

Eugenics, from the Greek word eugenes (well-born), is generally understood as a set of beliefs and practices that aim to improve the genetic quality of the human population by preventing the potential reproduction of undesirable characteristics. First described by Francis Galton in 1883 , the concept predates the modern era, with evidence that Plato advocated for selective breeding principles as early as $400 \mathrm{BC} .{ }^{30}$ Understood today, however, the idea of eugenics is often associated with white supremacism and, later, Nazism. By the early twentieth century, a eugenics movement that emerged in the United Kingdom had spread across Europe and into the United States and Canada. Eugenic ideas influenced policy and in some cases law, with the intention of enhancing a population's genetic stock by encouraging those deemed fit to reproduce to have children and prohibiting those considered unfit from breeding. In Canada, such negative measures included forced sterilization of people with mental or physical disabilities, criminals, those with low IQs, and members of certain minority groups. In Germany, the Nazi Party adopted eugenics policies, taking the negative measures to an extreme with its Final Solution for eradicating the Jewish race.

\footnotetext{
28 Reprinted as Adolf Brand, "What We Want," in Oosterhuis and Kennedy, eds., Homosexuality and Male Bonding in Pre-Nazi Germany, I55-I66 (I60).

29 Reprinted as Adolf Brand, "Friend-love as a Cultural Factor: A Word to Germany's Male Youth," in Oosterhuis and Kennedy, eds., Homosexuality and Male Bonding in Pre-Nazi Germany, I45-54 (I48).

30 See: Francis Galton, "Eugenics: Its Definition, Scope, and Aims," American Journal of Sociology X, no. I (1904): 82, doi:10.1038/070082ao.
} 
Many members of the Gemeinschaft were not only adherents of eugenics, but in some ways complicit with the promotion of a belief that the German race was superior to other races and under threat from undesirable breeding. The association between Brand and eugenics, as expressed through many of the nude images he published, points to Der Eigene's complicated legacy. At its foundation, the Gemeinschaft was a nationalistic and right-leaning association, and members espoused many of the same beliefs that would later become associated with fascism and Nazism. This complicated legacy is exactly why, as noted above, Oosterhuis begins his anthology by stating that he will present selected texts from Der Eigene as is, to allow readers to judge for themselves their merit or place in gay history. ${ }^{3 \mathrm{I}}$ The irony of Der Eigene is that many of the ideals it propagated on the assumption of advancing homosexuality were nationalized once the Nazi Party took control of government and adopted a similar notion of "manly culture" for Germany. Within this "manly culture," homosexuals were among the first to be persecuted, beginning with the extrajudicial execution of Ernst Röhm in 1934 .

The relationship between Brand and Röhm is also worth noting. As early as I93I, Brand wrote about the perceived threat of homosexuality to Nazism in a publication called Eros, also produced by the Gemeinschaft. Röhm was a highly ranked Nazi officer whose homosexual inclinations were exposed by the liberal press when some of his private correspondence was publicly released. ${ }^{32}$ In Eros, Brand writes: "The threatened hanging on the gallows, with which they allege they want to exterminate homosexuals, is therefore only a horrible gesture that is supposed to make stupid people believe that the Hitler people, in the matter of male-to-male inclination, are all as innocent as pigeons and pure as angels, just like the pious members of the Christian Society of the Virgin." 33 No doubt the Nazi party was paying attention to Brand and his public criticism of Hitler's party. Jason Crouthamel reminds us that it was Röhm who took possession of the materials confiscated from the raids of Brand's home in 1933, but it was also not the first time that Röhm had interacted with

Oosterhuis, "Homosexual Emancipation," 20-2I.

32 Reprinted as Adolf Brand, "Political Criminals: A Word about the Röhm Case," in Oosterhuis and Kennedy, eds., Homosexuality and Male Bonding in Pre-Nazi Germany, 235-39 (237).

33 Brand, "Political Criminals," 236. 
the Gemeinschaft. ${ }^{34}$ Brand and Röhm both argued for the benefits of a Männerbund (masculine society) because, as Röhm claims, the conception of masculinity is "rooted in ideals of comradeship and front-line discipline-regardless of whether one was a homosexual." ${ }^{35}$ Röhm even corresponded with Karl-Günther Heimsoth, a contributor to Der Eigene, to express his admiration for the ultra-masculine warrior archetype. The Nazis were keenly aware of the associations between homosexuality and the Männerbund. Unfortunately for both Brand and Röhm, however, this was inconsistent with the idea of "hegemonic masculinity," and the Nazi Party moved to purge all homosexuals from service, beginning in June 1934 with the Night of the Long Knives. ${ }^{36}$

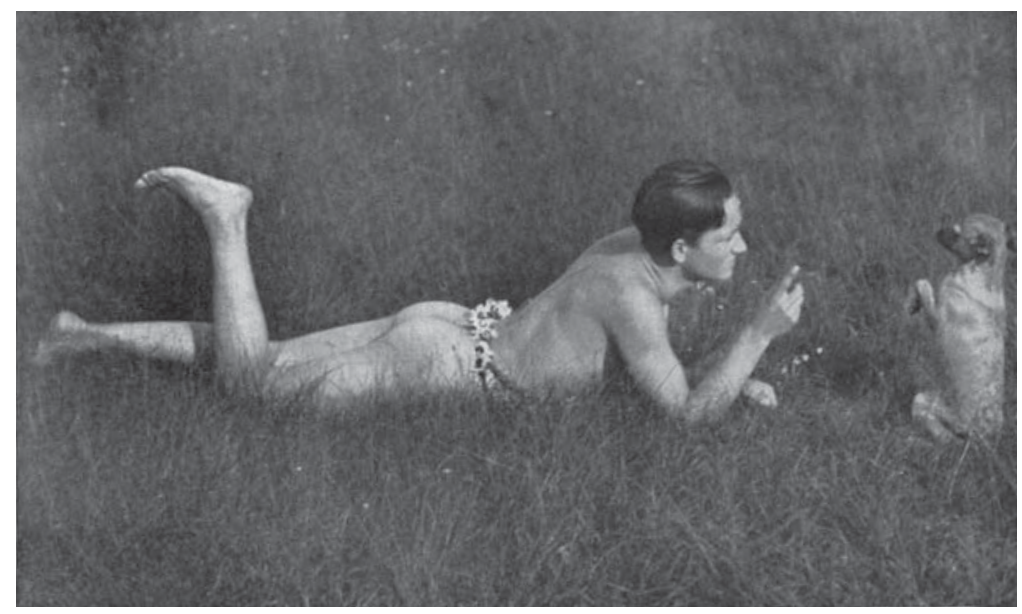

\section{Confronting the Effeminate Homosexual Minority}

Interestingly, it is the same nationalistic and masculinist beliefs that led to a purge of homosexuals from Germany which has also resulted in the marginalization of Der Eigene from contemporary ideas about LGBTQ history. In this last section, I would like to offer some insights into how these masculinist beliefs were articulated in

34 Jason Crouthamel, "Homosexuality and Comradeship: Destabilizing the Hegemonic Masculine Ideal in Nazi Germany," Central European History 5I, no. 3 (2018): 419-39 (426), doi: I0.10I7/Sooo8938918000602.

35 Crouthamel, "Homosexuality and Comradeship," 425.

36 Ibid., 427. 
the journal and by its proponents, and suggest reasons why further study of this magazine and its content are critical to understanding LGBTQ issues in contemporary society. While this article provides only an introduction to the journal and its bibliographical contexts, my goal is to expose the importance of recovering this history, as its influence remains misunderstood and often relegated to footnotes.

As explained above, Der Eigene was the main publication of Brand's society, the Gemeinschaft der Eigenen. For many of the reasons described earlier, few records survive that can help provide information about this society or its members. We know that the journal likely had fewer than I,500 subscribers, and a subscription was included in membership in the Gemeinschaft, which was founded in 1903. ${ }^{37}$ While Der Eigene was the Gemeinschaft's main publication, it also published other titles such as a weekly report, Wochenberichte der Gemeinschaft der Eigenen, and an occasional supplement, Extrapost der Eigenen, as well as the aforementioned Eros, which was an annual similar to the Jahrbuch für sexuelle Zwischenstufen published by Hirschfeld's Scientific-Humanitarian Committee. ${ }^{38}$

Brand began his career as an activist working in concert with Hirschfeld; they collaborated together in 1896 to plan a campaign to abolish Paragraph 175. Yet, while the Scientific-Humanitarian Committee's main focus remained the decriminalization of homosexuality and support for those who had been charged under Paragraph 175 or were threatened with blackmail, Brand's Gemeinschaft was much broader in its scope. Brand spells out the Gemeinschaft's twenty priorities in a 1925 statute, titled "What We Want"; these include: freedom and love, a more liberal sexual culture, the end of prostitution and the seduction of girls, and so on. Only in priority number eighteen does he mention a desire to repeal Paragraph 175. A reflection of these broader priorities, Der Eigene also included content that was focused more on protection and comradeship for members than on political goals. Members, for example, could place personal ads in the society's publication. At the end of a 1925 issue, one ad reads, "pensionless language teacher and disheartened soldier looking for a solid commitment abroad." 39 Another reads, "retired

\footnotetext{
Oosterhuis, "Homosexual Emancipation," 3.

Ibid., 4 .

39 Brand, ed., Die Tänte, 443.
} 
bookseller, who spent many years abroad before the war, looking for a position as a translator or correspondent." 40

Not surprisingly, the relationship between Brand and Hirschfeld quickly soured. Not only did the two have different priorities, but they also viewed homosexuality through opposing lenses. While Brand advocated for the acceptance of homosexuality through art and literature, often with arguments promoting the sexual health and racial purity of Germans, Hirschfeld advocated for the rights and social status of an "effeminate homosexual minority," whom he described as Urninge (Uranians). The concept of the Urning was first introduced in the mid-I8oos by Karl Heinrich Ulrichs to describe a person with "a female psyche in a male body," or any man who is sexually attracted to other men. ${ }^{4 \mathrm{I}}$ Contributors to Der Eigene, including Brand, began to express their dislike, and in many cases abhorrence, of the sort of homosexuality advocated by Hirschfeld and his fellow sexologists. Members of the Gemeinschaft regarded Urninge as degenerate and inferior to the idealized masculine archetypes promoted in Der Eigene, and frequently used the journal to articulate this perspective. In fact, Brand's disdain for Hirschfeld was so intense that, in 1925, the Gemeinschaft published an entire issue of Der Eigene dedicated to ridiculing and discrediting him. In one essay, Peter Hamecher refers to a survey conducted by the Scientific-Humanitarian Committee to suggest that "the 'Urnings' will find exquisite opportunity to be coquettish about their valued bodily and mental characteristics, such as they are: dazzling white skin, curly hair, beautiful eyes, a preference for Heine's 'Book of Songs,' for cooking, embroidering, knitting, sewing, and such, not to forget looking in the mirror. Oh how splendid! Oh how lovely!"42

Hamecher, who had been involved with the Gemeinschaft since at least 1903 and frequently wrote for Der Eigene, shows incredible contempt for effeminate men. In fact, the entire issue, titled Die Tänte, or "aunties," a derogatory word for effeminate men, includes content specifically designed to mock Hirschfeld and his concept of the Urning. ${ }^{43}$ The cover depicts a caricature of a man dressed as a

\footnotetext{
40 Brand, ed., Die Tänte, 443.

${ }^{4}$ See: Karl Heinrich Ulrichs, The Riddle of "Man-Manly" Love: The Pioneering Work on Male Homosexuality, trans. Michael A. Lombardi-Nash, 2 vols. (Buffalo: Prometheus Books, 1994), 309.

42 Reprinted as Peter Hamecher, "Love," in Oosterhuis and Kennedy, eds., Homosexuality and Male Bonding in Pre-Nazi Germany, 49-5I (50).

43 Brand, ed., Die Tänte.
} 
woman, complete with large hat and veil, excessive blush and lipstick, a heavily contoured nose, and even a small beauty mark on his cheek.

Oosterhuis notes that Brand "seems to have been rather opportunistic in accepting anyone who might share his dislike of Hirschfeld." 44 Members of the Gemeinschaft included some prominent figures in German society, such as poet Peter Hille, scholar Paul Brandt, and Wilhelm Jansen, a writer and poet who was also a leader in the Wandervogel (Bird of Passage) youth movement. Wandervogel sought to resist industrialization by taking members on hikes through the German countryside; Wilhelm led a splinter group, Jung-Wandervogel (Young Bird of Passage), which was known for the prevailing homosexuality among its ranks and for its focus on youth culture against the institutional constraints of adulthood. ${ }^{45}$ Der Eigene published writing and artwork by the painter known as Fidus (Hugo Höppener), sociologist Benedict Friedlaender, writer Klaus Mann, and the essayist Hamecher. Most Der Eigene contributors were, however, unknown to the broader social or political public, and represented a fairly diverse range of political allegiances, social beliefs, and ideals. Brand also wrote articles for Der Eigene and took many of the photographs he published. His willingness to publish any content that was critical of Urninge, however, sometimes resulted in mudslinging grounded in anti-Semitic attacks on the German-Jewish Hirschfeld. Brand attempted to distance himself from this kind of vitriolic attack by placing disclaimers at the bottom of articles: "We leave room for this scientifically objective article without identifying ourselves with the authors in every detail (anti-Semitism)." 46 The association between Brand and anti-Semitism nevertheless factors into the many reasons why the journal has been neglected by researchers in favour of sexology texts.

Still, even though Brand continued to express exasperation at the influence of the Scientific-Humanitarian Committee over the press and the homosexual movement, Hirschfeld gained considerably more notoriety and attention than Brand's Gemeinschaft. One reason for this may be that Brand and Der Eigene often risked trouble with the

44 Harry Oosterhuis, "Political Issues and the Rise of Nazism: Introduction," in Oosterhuis and Kennedy, eds., Homosexuality and Male Bonding in Pre-Nazi Germany, 183-92 (184).

45 John Alexander Williams, "Ecstasies of the Young: Sexuality, the Youth Movement, and Moral Panic in Germany on the Eve of the First World War," Central European History 34, no. 2 (2001): 163-89. 
law. Brand was imprisoned in 1900 for striking a member of the Reichstag (parliament) with a dog whip, which, as Keilson-Lauritz points out, led to considerable publicity for Brand. ${ }^{47}$ This incident led to a pause in production of Der Eigene which lasted until 1903. Brand was also involved in several lawsuits, such as the previously mentioned case involving nude photographs that resulted in a twomonth prison sentence-another gap in publishing the journal. Brand was also the only person imprisoned after the Harden-Eulenburg scandal (1907-09), which involved a series of courts-martial and civil trials regarding accusations of homosexual conduct among members of Kaiser Wilhelm II's cabinet and inner circle. Brand, who had printed a pamphlet describing how one German statesman, Bernhard von Bülow, had been blackmailed for his sexuality, was charged with libel and found guilty. He was sentenced to another eighteen months in prison. Each time Brand went to court, he gained more attention for his political cause, but he also incurred great risks. Consequently, he was cautious about the circulation of his controversial journal. The I906 special edition even includes a disclaimer stating that buyers are asked to sign a waiver indicating that they were interested in art and literature, and especially in "unconcealed representations of the human body." ${ }^{8}$ Each person who purchases a copy is directed to write their name on the cover on a line provided. ${ }^{49}$ It is likely that the Gemeinschaft was a relatively small affair and that the ideas espoused in Der Eigene, in turn, reached a fairly small audience. Whereas Der Eigene was typically thirty to sixty pages long, usually with a circulation of around I,500, the Jahrbuch für sexuelle Zwischenstufen often ran above a thousand pages and potentially reached tens of thousands of readers. One popular booklet published by the ScientificHumanitarian Committee in I9II, Was Soll das Volk vom dritten Geschlecht Wissen?, even had a print run of fifty thousand copies. ${ }^{50}$

Certainly, Hirschfeld and the ideas he presented on sex and sexuality have come to dominate the history of homosexuality. Not only are they compatible with a primary goal of gay liberation-to counter societal shame with gay pride, and gay and lesbian rights

Keilson-Lauritz, Die Geschichte, 85-88.

48 Brand and Linke, eds., Der Eigene: Ein Buch, v.

49 It is obvious that this practice was not always followed. For instance, the copy at the Thomas Fisher Rare Book Library (K-II 00373), University of Toronto, is not signed on the line provided, which implies that not every copy was sold in this way.

so Beachy, "German Invention," 824. 
movements-but they also align with contemporary queer and trans movements, which emphasize sexual and gender diversity and recognize intersectional identities. Hirschfeld's identity as a persecuted gay German Jew is also more sympathetic than Brand's role in advocating for the same kind of eugenics that mobilized the Holocaust. Not all of Brand's legacy, however, is marred by his distasteful ideas about racial purity and sexual health. As Oosterhuis points out, there is still much of value to be found in the study of Der Eigene. It is, after all, the first homosexual periodical and thus occupies an important place in the history of sexuality. Published at a time when homosexuality was illegal in Germany, it included content by men who were willing to attach their names to articles, artworks, and literature with the explicit intention of promoting friend-love between and among men. If, as Beachy claims, Germany is the birthplace of homosexuality, then it is important to examine the milieu from which this category of sexual identity arose. ${ }^{\mathrm{SI}}$ Brand and Der Eigene are part of this context. Der Eigene also demonstrates just how liberal the Weimar Republic was, as Brand and his contributors often pushed against the limits of acceptability and tolerance. The journal provides insight into the thoughts and feelings of men as they explored their shared identities through new ways of conceiving same-sex love and desire.

\section{Manly Culture Today}

Brand's idea of racial and bodily purity, as manifest through the model of the inherently bisexual Übermensch and the opposition of Brand's Gemeinschaft toward effeminate homosexuality, highlights a longrunning tension within the contemporary gay community. The importance of physical health and fitness, hyper-masculinity, and white supremacy find modern parallels in the experiences of some queer people of colour, trans people, and others who do not achieve the standards of beauty as set by a white, cisgender, and masculine gay culture. This is obvious in studies of bar culture, sport, and even online dating profiles. Xiaofei Liu, for example, points to what he calls "a frequent caveat in online dating profiles-'No fats, femmes,

5I Beachy, "German Invention," 80I-38. 
or Asians." " ${ }^{2}$ Liu explores how some gay men express sentiments of "racial lookism" as simply a case of personal preference, and says that this practice is immoral and that the caveat is "an overgeneralization that disrespects individuality by treating people as exchangeable tokens of one type." ${ }^{53}$ Brand and his followers may not have termed their preference for racial and bodily purity as a "personal preference," but their idealization and adoration of one aesthetic over others is reminiscent of racial lookism. The fact that Brand, who advocated for the acceptance and superiority of the homosexual, might also be described as a right-wing nationalist could provide a model for understanding how an organization like the Log Cabin Republicans, which operates within the US Republican Party, would endorse the 2020 presidential re-election campaign of Donald J. Trump, despite Trump's active role in dismantling existing rights for LGBTQ people. What appears as a counterintuitive stance on the part of gay men might in fact share its roots with the kind of nationalism espoused in Der Eigene. This lineage is worthy of further investigation.

Other views expressed in Der Eigene also find modern parallels on the fringes of the LGBTQ community. Jack Donovan, for example, is an American author and critic of "anti-male feminism, victim mentality, and leftist politics." ${ }^{44}$ Although Donovan came out as gay in the I990s, participated in pride marches, and "hung out with drag queens," he later decided that he could not be gay because he was an "unrepentant masculinist." 55 He took up trades, studies martial arts, and now calls himself an "androphile," a term he appropriated to describe a man whose love of masculinity includes sexual activities with other men. In "A Thing for Men in Uniforms," James Kirchick describes how Donovan represents a small but active community of men invested in a "macho gay male identity" with strong ties to white nationalism and misogynist ideals. ${ }^{56}$ Another prominent member of this community is James J. O'Meara, an influential figure in the alt-right movement and a known Holocaust denier. In The Homo and

52 Xiaofei Liu, "No Fats, Femmes, or Asians," Moral Philosophy and Politics 2, no. 2 (2015): 255-76 (255), doi: I0.1515/mopp-2014-0023.

53 Ibid., 256.

54 Maureen O'Connor, "The Philosophical Fascists of the Gay Alt-Right," New York, 30 April 2017, https://www.thecut.com/2017/04/jack-donovanphilosophical-fascists-of-the-gay-alt-right.html.

55 Quoted in O'Connor, "Philosophical Fascists," 2017.

56 James Kirchick, "A Thing for Men in Uniforms," New York Review of Books, I4 May 2018. 
the Negro, O'Meara not only fuels the conspiracy theory that Jewish people are organizing to take over Western civilization-supported by "libidinous and demonic" black men ${ }^{57}$ — but also argues that the best defence against this threat is to embrace male bonding. Gay white men, O'Meara asserts, are the best representation of Western culture, the embodiment of Übermensch, because of their beauty and intelligence. As Kirchick explains, the views of Donovan and O'Meara echo those of Brand and other followers of the Männerbund. Although he does not explore the connections between the persistent presence of gay men in white supremacist movements in any depth, he notes the lineage between Der Eigene and this modern genre of "ultra-masculine" writing. ${ }^{58}$

Another example of the Übermensch in modern gay culture is the highly stylized erotic art of Tom of Finland. A pseudonym of Finnish illustrator Touko Valio Laaksonen, Tom of Finland produced more than 3,500 drawings over four decades, mostly featuring men with exaggerated musculature and masculine features, either wearing tight clothing or partially clothed. Reminiscent of Brand's nude photography, this homo-fetish artwork has had an influence on gay culture throughout the twentieth century, and its depictions of men have become central to the beefcake genre of pornography popular throughout the I970s and 1980s. He also developed a friendship with American photographer Robert Mapplethorpe, whose images frequently depicted gay men in fetish gear or engaged in BDSM sexual activities. Unlike Brand, however, Laaksonen claimed that his drawings have "no political statements to make, no ideology ... The whole Nazi philosophy, the racism and all that, is hateful to me, but of course I drew them anyway-they had the sexiest uniforms!" 99 Laaksonen later disavowed his erotic treatments of men in Nazi uniform, and these are typically left out of more recent anthologies of his work. F. Valentine Hooven notes that Laaksonen also included Black men in many of his drawings without overt racial or political overtones, suggesting that he was more concerned about hypersexuality and masculinity than whiteness. ${ }^{60}$ Whether Laaksonen identified with fascism or not, however, Tom of Finland's appeal is

\footnotetext{
57 Kirchick, "A Thing for Men in Uniforms."

58 Ibid.

59 F. Valentine Hooven III, Tom of Finland: His Life and Times (New York: St. Martin's Press, 1993), 30.

6o Hooven, Tom of Finland, 1993.
} 
that of the Übermensch, and this portrayal of masculinity as a peak gay representation persists today.

After the 1933 raids, Adolf Brand gave up his homosexual activism and sent a final letter to members of the Gemeinschaft der Eigenen, a section of which is published at the top of this article. The raids had left him in financial ruin and destroyed his life's work. He was not, however, imprisoned again. Brand and his wife, Elise Behrendt, were killed by an Allied bomb on I February 1945. While it may be tempting to relegate Donovan and O'Meara to mere footnotes, as Der Eigene has been in much of queer historiography, or to consider Tom of Finland's images as just men in "sexy uniforms," this lineage which includes Brand, eugenics, and the Übermensch deserves further contemplation. How can ideas espoused seventy years before Stonewall shed light on queer sexuality today? Der Eigene is an interesting and valuable historical antecedent to the rise of gay print in the r960s and 1970s. Although Brand and his followers championed distasteful and arguably dangerous ideas about sexuality, gender, and white supremacy, Der Eigene is a lens through which we can better understand the appeal of Donovan, O'Meara, and Tom of Finland, among others. It may also help us to understand why the preservation of a particular expression of masculinity was a dominant theme in Nazism and one that continues to be celebrated in contemporary alt-right and fascist communities today.

\section{Author Biography}

Andrew Stewart is the Reading Room Coordinator at the Thomas Fisher Rare Book Library, University of Toronto Libraries. He holds an MA (History) and a MISt from the University of Toronto. 